\title{
Application of Fluoride Technology for Processing of Off-Grade Aluminum Raw Materials
}

\author{
I. Burtsev, I. Perovskiy ${ }^{(凶)}$, and D. Kuzmin \\ Institute of Geology named after Academician N.P. Yushkin Komi Science \\ Center of the Ural Branch of the Russian Academy of Sciences, \\ Syktyvkar, Russia \\ igor-perovskij@yandex.ru
}

\begin{abstract}
We used the process of hydrofluoride desilication for off-grade aluminum raw materials widely distributed in the Komi Republic. The optimal ratios of fluorinating agent $\left(\mathrm{NH}_{4} \mathrm{HF}_{2}\right)$ to the target component $\left(\mathrm{SiO}_{2}\right)$ were determined by the method of differential thermal analysis. At a fluorination temperature $300{ }^{\circ} \mathrm{C}$ and timing 30 min, we obtained concentrates containing up to $80 \% \mathrm{Al}_{2} \mathrm{O}_{3}$ and up to $10 \% \mathrm{SiO}_{2}$.
\end{abstract}

Keywords: Bauxite $\cdot$ Aluminum raw materials $\cdot$ Desilication $\cdot$ Fluorination $\cdot$ Ammonium hydrofluoride

\section{Introduction}

One of the most important problems of Russian aluminum industry is the deficit of high-quality alumina raw materials, forcing to import it from other countries.

A major source of alumina raw materials is the Vezhayu-Vorykvinskoe and Verkhneshchugorskoe bauxite deposits, which are part of the Vorykvinskaya group of deposits in Middle Timan and developed by the United Company RUSAL. Mined bauxites are predominantly consumed for alumina production by the Bayer method.

The share of low-quality sintered bauxites is significant and amounts from 5 to $55 \%$ of balance reserves for Vezhayu-Vorykvinskoe and Verkhneshchugorskoe deposits. A sharp reduction in consumption of sintered bauxites makes an alternative processing a rather actual question. In addition, the prospected reserves contain a significant amount of off-balance ores, off-grade in quality: high-silica low-modulus (better $\mathrm{M}_{\mathrm{Si}}$ 2.6-3.8) bauxites and associated high-aluminous allites.

Gravitational, flotation, magnetic, chemical, and other methods have been proposed to enrich the bauxites, but their use for enriching Middle Timan bauxite is limited due to a fine size of the minerals, a large proportion of amorphous phases, and a small efficiency of used processes in general (Burtsev et al. 2016).

Fluoride technologies are one of the most promising ways to process mineral raw materials (Dyachenko and Kraidenko 2007; Medkov et al. 2011). The purpose of the research - to assess the prospects for the use of fluorination to desilicate off-grade 
aluminum raw materials (bauxite, allite, kaolinite clays), which are widespread in the Komi Republic.

\section{Methods and Approaches}

The objects of research - representative samples of bauxite, allite, kaolinite clays from the Vezhayu-Vorykvinskoe (V-V), Verkhneshchugorskoe (Vsch) deposits and occurrences of the Izhma area (IA). Samples were grinded in a disk eraser (ID-200) and separated by size classes $0.125-0.250$ and $0.25-0.5 \mathrm{~mm}$. Analytical work was carried out by the equipment of the Center for Collective Use GeoScience of the Institute of Geology Komi SC UB RAS using XRD, XRF, DTA. Fluorination was carried out in a tube furnace equipped with a gas-extraction system. Ammonium hydrodifluoride $\left(\mathrm{NH}_{4} \mathrm{HF}_{2}\right)$ was used as a fluorinating component, which is an ecologically safe matter under standard conditions.

\section{Results and Discussion}

X-ray fluorescence analysis showed that the granulometric differentiation did not lead to a change in the chemical composition and silicon module of the samples (Table 1). We diagnosed reflexes of kaolinite with hematite admixture on diffraction patterns of samples No. 1, 2, and 3, and boehmite, kaolinite with anatase admixture on the patterns of sample No. 4.

Table 1. Chemical composition of off-grade bauxite ores

\begin{tabular}{|c|c|c|c|c|c|c|c|c|}
\hline \multirow[t]{2}{*}{ No. } & \multirow[t]{2}{*}{ Class, $\mathrm{mm}$} & \multicolumn{6}{|c|}{ Mass fraction, $\%$} & \multirow[t]{2}{*}{$M_{S i}$} \\
\hline & & $\mathrm{Al}_{2} \mathrm{O}_{3}$ & $\mathrm{SiO}_{2}$ & $\mathrm{Fe}_{2} \mathrm{O}_{3}$ & $\mathrm{TiO}_{2}$ & $\mathrm{MgO}$ & $\mathrm{K}_{2} \mathrm{O}$ & \\
\hline 1 & $0.25-0.5$ & 43,82 & 50,83 & 2,93 & 1,66 & 0,31 & 0,10 & 0.86 \\
\hline IA & $0.125-0.25$ & 44,08 & 50,76 & 2,70 & 1,66 & 0,31 & 0,10 & 0.86 \\
\hline 2 & $0.25-0.5$ & 43,32 & 48,40 & 4,96 & 1,59 & 0,67 & 0,67 & 0.88 \\
\hline Vsch & $0.125-0.25$ & 43,63 & 48,67 & 3,92 & 1,78 & 0,79 & 0,71 & 0.90 \\
\hline 3 & $0.25-0.5$ & 35,94 & 39,83 & 19,84 & 1,37 & 1,76 & 0,68 & 0.90 \\
\hline $\mathrm{V}-\mathrm{V}$ & $0.125-0.25$ & 36,01 & 39,99 & 19,75 & 1,27 & 1,77 & 0,65 & 0.90 \\
\hline 4 & $0.25-0.5$ & 59,85 & 23,91 & 12,98 & 1,12 & 1,03 & 0,61 & 2.50 \\
\hline Vsch & $0.125-0.25$ & 59,37 & 23,78 & 13,53 & 1,15 & 1,04 & 0,62 & 2.50 \\
\hline
\end{tabular}

Admixture components $\mathrm{Na}_{2} \mathrm{O}, \mathrm{CaO}, \mathrm{MnO}, \mathrm{P}_{2} \mathrm{O}_{5}$ no more than $0.8 \%$.

Thermodynamic calculations of fluorination of kaolinite $\mathrm{NH}_{4} \mathrm{HF}_{2}$ are given elsewhere (Rimkevich et al. 2016). However, the theoretical equation turns out to be complicated in stoichiometric terms, which leads to the overconsumption of the fluorination component. Our works on fluorination of titanium ores of the Yarega deposit in the Komi Republic showed the efficiency of applying the ratio calculation to the target component-silicon oxide (Perovskiy and Ignat'ev 2013; Perovskiy and Burtsev 2016). $\mathrm{SiO}_{2}$ fluorination can be described by the following equation: 


$$
\mathrm{SiO}_{2}+3 \mathrm{NH}_{4} \mathrm{HF}_{2}=\left(\mathrm{NH}_{4}\right)_{2} \mathrm{SiF}_{6}+2 \mathrm{H}_{2} \mathrm{O}+\mathrm{NH}_{3} \uparrow
$$

We studied the process of fluorination of off-grade bauxites at molar ratios $\mathrm{SiO}_{2}$ : $\mathrm{NH}_{4} \mathrm{HF}_{2}$ equal to 1: 1 and 1: 1.5 with the help of DTA. We established that ratio 1:1 was preferred. Excessive ammonium fluoride (1:1.5) did not result in a positive effect, but was accompanied by passivation of fluorination reactions and formation of a larger volume of gaseous products.

Taking into account DTA data, the temperature regime of fluorination consisted of sintering the sample with $\mathrm{NH}_{4} \mathrm{HF}_{2}$ at temperature $200{ }^{\circ} \mathrm{C}$ (30 min.) with subsequent sublimation of resulting salt $\left(\mathrm{NH}_{4}\right)_{2} \mathrm{SiF}_{6}$ at $300{ }^{\circ} \mathrm{C}$ (30 min.). Upon completion of the fluorination, we carried out water leaching, which allowed transferring the undecomposed fluoroammonium salts into the solution.

The results of fluorination, given in Table 2, show that $\mathrm{SiO}_{2}$ content is significantly reduced in the samples. At the same time, the size of material does not affect the effectiveness of desilication.

Table 2. Chemical composition of samples after fluorination

\begin{tabular}{l|l|l|l|c|l|l|l}
\hline \multirow{2}{*}{ No. } & Class, $\mathrm{mm}$ & \multicolumn{6}{|l}{ Mass fraction, \% } \\
\cline { 3 - 8 } & & $\mathrm{Al}_{2} \mathrm{O}_{3}$ & $\mathrm{SiO}_{2}$ & $\mathrm{Fe}_{2} \mathrm{O}_{3}$ & $\mathrm{TiO}_{2}$ & $\mathrm{MgO}$ & $\mathrm{K}_{2} \mathrm{O}$ \\
\hline 1 & $0.25-0.5$ & 80.77 & 7.75 & 6.75 & 3.60 & 0.33 & 0.25 \\
$\mathrm{IA}$ & $0.125-0.25$ & 81.17 & 7.73 & 6.78 & 3.67 & 0.32 & 0.23 \\
\hline 2 & $0.25-0.5$ & 73.94 & 8.98 & 9.85 & 3.92 & 1.03 & 1.66 \\
Vsch & $0.125-0.25$ & 71.81 & 11.24 & 10.07 & 3.67 & 1.00 & 1.58 \\
\hline 3 & $0.25-0.5$ & 55.07 & 7.28 & 30.20 & 2.38 & 2.72 & 1.40 \\
V-V & $0.125-0.25$ & 52.87 & 9.17 & 30.61 & 2.29 & 2.74 & 1.36 \\
\hline 4 & $0.25-0.5$ & 68.00 & 9.99 & 17.55 & 1.45 & 1.46 & 1.01 \\
Vsch & $0.125-0.25$ & 67.31 & 9.67 & 18.52 & 1.48 & 1.44 & 1.02 \\
\hline
\end{tabular}

Admixture components $\mathrm{Na}_{2} \mathrm{O}, \mathrm{CaO}, \mathrm{MnO}, \mathrm{P}_{2} \mathrm{O}_{5}$ no more than $0.9 \%$.

\section{Conclusions}

The process of hydrofluoride desilication has been applied to off-grade aluminum raw materials widespread in the Komi Republic. The optimal ratio of $\mathrm{NH}_{4} \mathrm{HF}_{2}$ : $\mathrm{SiO}_{2}$ equal to 1:1 was determined by DTA method. At the fluorination temperature $300{ }^{\circ} \mathrm{C}$ and timing 30 min, concentrates with $\mathrm{Al}_{2} \mathrm{O}_{3}$ content more than $70-80 \%$, and $\mathrm{SiO}_{2}$ - less than $10 \%$ were produced. This technology is an alternative to the acid and alkaline processing of high-siliceous aluminum raw materials. The use of fluoride technology allows not only to improve the quality of ores because of desilication, but also to obtain products that can be directly processed by electrothermal methods to silumin (Lepezin et al. 2014), ferroalloys (Bukin and Seregin 2014) and other products with high added value.

Acknowledgements. The work was carried out with the financial support of the State task "Scientific basis for effective subsoil use, development and exploration of mineral resource base, 
development and implementation of innovating technologies and economic zoning of the TimanNothern Ural region" No. AAAA- A17-117121270037-4.

\section{References}

Bukin AV, Seregin AN (2014) Development of technology for smelting ferrosilicoaluminium from sub-standart bauxite and aluminous waste of metallurgy and electrical power energetic. Probl Ferr Metall Mater Sci (2):31-36

Burtsev IN, Kotova OB, Kuzmin DV, Mashin DO et al (2016) Prototypes of new technologies for development of the mineral raw materials complex of the timan-north urals region. In: Proceedings of the Komi science centre of the Ural division of the Russian academy of sciences, vol 27, no 3, pp 79-88

Dyachenko AN, Kraidenko RI (2007) Separation of silicon-iron-copper-nickel concentrate by fluorammonium method into individual oxides. Bull Tomsk Polytech Univ 311(3):35-38

Lepezin GG, An'shakov AS, Faleev VA, Avvakumov EG, Vinokurova OB (2014) Plasmachemical method of producing silumin and aluminium from the minerals of the sillimanite group. Doklady Chem 456(2):110-113

Medkov MA, Krysenko GF, Epov DG (2011) Ammonium bifluoride - the perspective reagent for complex processing of mineral raw materials. Vestn Far East Branch Russ Acad Sci. 159 (5):60-65

Perovskiy IA, Burtsev IN (2016) Influence of mechanical activation of leucoxene on efficiency of its processing by fluoride method. Perspektivnye Materialy (2):66-73

Perovskiy IA, Ignat'ev GV (2013) Ammonium fluoride method of desilication of leucoxene concentrate of Yarega deposit. In: Predictive estimate of technological properties of minerals by applied mineralogy methods. Proceedings of 7th Russian seminar of process mineralogy, Karelian Scientific Centre RAS, Petrozavodsk, pp 110-116

Rimkevich VS, Pushkin AA, Girenko IV, Leontyev MA (2016) Perspectives of complex processing the kaolin concentrates by hydrochemical method. Izv Samara Sci Cent Russ Acad Sci 18(2):186-190

Open Access This chapter is licensed under the terms of the Creative Commons Attribution 4.0 International License (http://creativecommons.org/licenses/by/4.0/), which permits use, sharing, adaptation, distribution and reproduction in any medium or format, as long as you give appropriate credit to the original author(s) and the source, provide a link to the Creative Commons license and indicate if changes were made.

The images or other third party material in this chapter are included in the chapter's Creative Commons license, unless indicated otherwise in a credit line to the material. If material is not included in the chapter's Creative Commons license and your intended use is not permitted by statutory regulation or exceeds the permitted use, you will need to obtain permission directly from the copyright holder.

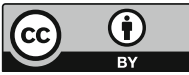

